\title{
JUDUL PENELITIAN \\ Pengaruh Daya Tarik Wisata Terhadap Minat \\ Kunjungan Ulang Wisatawan \\ di Museum Benteng Vredeburg Yogyakarta
}

\author{
Fitrotud Diniyah, Khoirullah \\ STP AMPTA Yogyakarta \\ Email: Diniyahf.10@gmail.com \\ DOI:
}

\section{PENDAHULUAN}

Pariwisata merupakan salah satu sektor yang sedang menjadi prioritas dari pemerintahan saat ini. Pada tahun 2017, devisa yang didapatkan dari sektor ini adalah yang terbesar ke empat setelah Migas, CPO, dan batu bara. Hal tersebut bukan sesuatu yang mengejutkan, sebab Indonesia memiliki destinasi wisata yang jumlahnya ribuan. Jenisnya pun sangat beragam sesuai dengan kekayaan alam, budaya, dan sejarah di Indonesia yang memiliki keunikan masing-masing. Pemerintah sedang menargetkan Pariwisata sebagai penyumbang devisa terbesar pada 2019. Untuk memenuhi target tersebut, pemerintah sedang mengembangkan 10 destinasi wisata prioritas, yakni Tanjung Kelayang, Tanjung Lesung, Mandalika, Morotai, Borobudur, Danau Toba, Kepulauan Seribu, Bromo Tengger Semeru, Wakatobi, dan Labuan Bajo, lalu ditambah lagi dengan 10 destinasi yang telah berkembang, seperti Wakatobi, Raja Ampat, Bunaken, Bali, Jakarta, Kepulauan Riau, Banyuwangi, Bandung, Solo, Semarang, dan Yogyakarta.

D.I Yogyakarta sendiri memiliki daya tarik wisata yang tidak akan mengecewakan para pengunjung. Sebutan Yogyakarta sebagai daerah pariwisata menggambarkan potensi provinsi ini dalam kacamata kepariwisataan. Berbagai jenis obyek wisata yang dikembangkan di wilayah ini seperti wisata alam, wisata sejarah, wisata budaya, wisata pendidikan, dan wisata belanja.

Salah satu tempat wisata bersejarah di Yogyakarta adalah Museum Benteng Vredeburg. Benteng Vredeburg ini merupakan saksi dari keberadaan VOC di Yogyakarta yang didirikan pada 1745 oleh pemerintah Belanda untuk menahan serangan dari Kraton Yogyakarta. Dengan parit yang mengelilinginya, benteng yang berbentuk segi empat ini memiliki menara pengawas di setiap sudutnya dan kubu yang memungkinkan tentara 
Telp (0274) 485-115 Tempel, Catur Tunggal, www.ampta.ac.id

Belanda untuk berjalan berkeliling sambil berjaga-jaga dan melepaskan tembakan jika diperlukan.

Benteng ini mulai diresmikan pada tahun 1992 sebagai Museum Khusus Perjuangan Nasional dengan nama Museum Benteng Vredeburg. Kemudian tanggal 5 September 1997, dalam rangka peningkatan fungsionalisasi museum, Museum Benteng Vredeburg Yogyakarta mendapat limpahan untuk mengelola museum Perjuangan Yogyakarta di Brontokusuman Yogyakarta

Museum bersejarah ini memiliki berbagai kelebihan, pertama adalah lokasinya yang strategis karena berdekatan dengan Malioboro yang selalu ramai dengan para wisatawan baik lokal maupun asing. Kedua adalah sejarahnya yang merupakan peniggalan dari kolonial Belanda di Yogyakarta dan hal ini adalah potensi dari museum benteng Vredeburg untuk dikenal masyarakat internasional. Ketiga, museum ini walaupun merupakan salah satu museum kolonial yang masih masih begitu terawat, dan juga memiliki berbagai fasilitas untuk memenuhi kepuasan para pengunjungnya, tiket masuknya pun sangat murah yaitu Rp3000 untuk pengujung dewasa lokal dan Rp10,000 untuk wisatawan asing.

Dalam dunia kepariwisataan, kepuasan dari wisatawan yang berkunjung ke sebuah destinasi merupakan syarat untuk menjaga keberlanjutan destinasi tersebut. Wisatawan yang merasa puas dengan pengalaman berwisatanya akan memiliki kecenderungan untuk kembali berkunjung (revisit) ke destinasi tersebut. Penelitian yang dilakukan Basiya dan Rozak yang bertujuan menganalisis faktor-faktor daya tarik objek wisata berdasarkan persepsi wisatawan serta pengaruhnya terhadap tingkat kepuasan dan niat kembali berwisata ke destinasi wisata di Provinsi Jawa Tengah. Kedua peneliti dengan menggunakan analisis jalur pada model regresi berganda menunjukkan wisata alam, buatan, sosial, dan budaya memberikan pengaruh positif terhadap kepuasan wisatawan. Selain itu wisata alam, buatan, sosial, dan budaya terbukti memberikan pengaruh positif terhadap niat berwisata kembali (Basiya \& Rosak, 2012).

Penelitian ini bertujuan untuk menganalisis hubungan antara daya tarik wisata dengan niat para wisatawan untuk kembali berkunjung ke destinasi Museum Benteng Vredeburg. Selain itu, juga ingin diketahui faktor-faktor yang berperan penting dalam menentukan tingkat kepuasan para wisatawan yang berkunjung ke Museum ini. 


\section{STP AMPTA Yogyakarta}

Telp (0274) 485-115 Tempel, Catur Tunggal, www.ampta.ac.id Depok, Sleman,

D.I.Yogyakarta

DAFTAR PUSTAKA

http:/ / www.yogyalagi.com/2015/09/museum-benteng-vredeburg-wisatasejarah.html (Diakses pada 17 februari 2018)

https://vredeburg.id/sejarah-singkat/ (Diakses pada 17 februari 2018)

https:/ / www.rappler.com/indonesia/berita/nasional/185679-tiga-tahunjokowi-jk-5-pencapaian-pariwisata (Diakses pada 23 februari 2018)

https://www.researchgate.net/publication/305807291_ANALISIS_KUNJU NGAN_ULANG_WISATAWAN_NUSANTARA_DENGAN_MODEL_KON STRUK_BERHIERARKI (Diakses pada februari 25 2018) 